\title{
The Metaphysical Essence of the Controversy between Proponents of Pro-choice and Pro-life Attitudes Intensified in Eastern European countries
}

\author{
Andrzej Brodziak ${ }^{1 *}$, Alicja Różyk Myrta ${ }^{2}$ and Jana Kutnohorska ${ }^{3}$ \\ 1Institute of Occupational Medicine and Environmental Health, Sosnowiec, Europe \\ 2Institute of Nursing, University of Applied Sciences, Europe \\ 3Department of Health Care Studies, Tomas Bata University, Europe
}

Submission: July 12, 2017; Published: July 24, 2017

*Corresponding author: Andrzej Brodziak, Institute of Occupational Medicine and Environmental Health, Koscielna St. 13, 41 - 200 Sosnowiec, Poland, Europe, Tel: (48 32) 26608 85; Fax: (48 32) 266 11 24, Email: andrzejbrodziak@wp.pl

\section{Introduction}

Today in various countries around the world there is a dispute on the acceptability and legality of abortion. In Poland in October 2016, the contestation between the proponents of socalled pro-choice and pro-life attitudes took the form of mass street protests. Understanding the causes of a violent reaction of women facilitates comprehension of the essence of the dispute. Data on these social changes can be helpful in analyzing and subduing similar controversies in other countries. In our opinion, understanding the causes of the ongoing culture war would requires a review of the historical development of views on the acceptability of abortion and a review of the current legislation and social circumstances in different countries of the world. Then it would be easier to characterize the reasoning of the proponents of pro-life and pro-choice attitudes.

The review of historical development and of current legislations were presented recently by some authors [1-9]. However, the most important element of the problem which is the essence of ideological controversy is not fully realized. For this reason, we focus in this commentary to attempt to capture the difference in reasoning of supporters of pro-choice and prolife attitudes. In our view, it is needed to distinguish between the average, popular, circulating ideas assumed by the broad general parties and the differences in philosophical arguments to which some participants of the dispute refer. This will allow presenting the trial of explanation of recent exacerbation of the contestation.

An Attempt to Characterize the Reasoning of Proponents of the Pro-Life Attitude

In the course of typically emotional conversations with people who are supporters of pro-life attitudes, the following arguments and inference reasoning are formulated: Biological life, human life exists from the moment of fertilization, it means from the moment of the appearance of a single cell-the zygote. Human life is sacred, blessed («holy») and therefore should be subjected to legal and practical protection from that moment. The proponents of a pro-life attitude identify the zygote, the early stages of development of the embryo and fetus with the "human person». The supporters of the pro-life attitude are convinced that 1 . Their opinions result from religious doctrine, and that 2 . It is the only proper attitude in the light of current morality.

Their knowledge and convictions are based on the recent declarations of the hierarchs of the Church, and as the basis for moral evaluation they apply the current guidelines of the Catholic Church. The proponents of pro-life attitudes do not generally know the history of the development of the position of Christian churches for the admissibility of abortion, and their moral judgment is not subject for analysis from the point of view of different ethical schools. In talks with supporters of pro-life attitudes, it is difficult to discuss the essence of the phenomenon of life and details of current knowledge related to this phenomenon (DNA, genome, cellular cytoplasm) as well as knowledge about the natural processes of the loss of the early form of embryos by failure of implantation and early miscarriage.

It seems that mainly on a subconscious level they place an extremely high value on the existential events involving the occurrence of the sexual intercourse, regardless of the circumstances and the intentions of the couple who conceived the zygote, embryo, man. Even if the intention was not noble (casual intercourse without the intention of procreation, or even with conscious exclusion of the intention to conceive offspring, 
or as a result of rape) - the memory and awareness of the occurrence of sexual intercourse establishes the sanctification of the embryo. One could express this subconscious attitude by the phrase: «if you remember that you had sexual intercourse you are obliged irreversibly to protect the unborn embryo, regardless of your partner's emotional attitude and the expected future fate of the child".

The pro-life attitude is usually accompanied by attempts to change legislation related to the possibility of abortion. Amazingly, some of the people actively involved in the fight for such legislative regulations are men. Talking with these people shows that they exhibit the characteristics of religious fundamentalism focused on sexuality.

\section{An Attempt to Characterize the Reasoning of Proponents of the Pro-choice Attitude}

Women opting for the right to make decisions about pregnancy justify their position as follows: Zygote, embryo, the early stages of development of the fetus are part of a woman's body. It happens that these cells die like many other cells in the human body. There is a permanent, frequent loss of unimplanted embryos and early pregnancy loss. There are no reasons to treat the early form of the embryo as a person. Treating the fetus as a separate person is justified only after the appearance of the action of the nervous system of the fetus, or even after the beginnings of his self-awareness, which comes into play only after 10 - 12 weeks of pregnancy.

The decision to be a mother is an inalienable right of a woman who can make it depending on the relationship with her partner, a real desire to have a child and other emotional and social circumstances of living. Particularly important here are the determinants of health and anticipated well-being (quality of life) depending on the contemplated planned decision. Making decisions about motherhood is the responsibility of her personal choice, which should not be affecting by the views or regulation, dictated by unacknowledged ideological assumptions.

Women opting for the right to make their own decisions about motherhood in particular, do not agree to changes in the legal regulations concerning the well-known exceptional cases, mentioned in the present restrictive legal regulations in force in Poland (pregnancy as consequence of rape, the threat of the woman's life or health, irreversible damage to the fetus). These women have a high sense of dignity and attribute great importance to their relationship and feelings for their partners and children. The rights of adult women cannot in their eyes stand above the rights of an unconscious embryo.

To be in favor of the pro-choice attitude is usually a component of a broader set of beliefs that characterize people with a liberal-minded, democratic, libertarian and secular worldview. Some of these people declare themselves to be agnostic or atheist, however, many of these women stated that they are believers. In some Eastern Europe countries, the secular views of the worldview may be derived not so much from the liberal, democratic, enlightened tradition but were established by left-wing socialist regimes.

\section{The Main Philosophical Arguments of the Two Parties of the Dispute}

The unique mention of abortion in the Old Testament is the following passage 21: 22 of the Book of Exodus: [Exodus 21: 22. If people are fighting and hit a pregnant woman and she gives birth prematurely but there is no serious injury, the offender must be fined whatever the woman's husband demands and the court allows. 23. But if there is serious injury, you are to take life for life, 24. Eye for eye, tooth for tooth, hand for hand, foot for foot].

St. Augustine (354 - 430 A.D.), one of the most influential Catholic theologians of the middle Ages promoted the concept of «delayed ensoulment.» He wrote that a human soul cannot live in an unformed body. Thus, an abortion in early in pregnancy according to him is not murder because no soul is destroyed or, more accurately, only a vegetable or animal soul is terminated [10]. He believed, however, that abortion of the formed fetus, called "animatus», i.e. "having limbs and shape", is murder. His standpoint on the termination of early pregnancy was inspired by the opinions of Aristotle. The influential, well-known theologian, founder of the dogmatic foundations of Christianity Thomas Aquinas (1225 - 1274 A.D.) also considered only the abortion of an «animated» fetus as murder [10].

The hierarchs of the Catholic Church began to take a more assertive, unfavorable position on the practice of abortion only in the sixteenth century. A rigorous position on abortion was declared by Pope Sixtus V in 1588 and it was repeated by Pope Gregory XIV in 1591. In the mid-nineteenth century, the attitude of the church hierarchy condemning women for interrupting pregnancy greatly intensified. Pius IX in 1869 abolished the distinction between the «fetus animatus» and «fetus inanimatus». At that time in many countries restrictive regulations were implemented.

The disputes of theologians were undertaken by contemporary professional philosophers. In his well-known articles, K.E. Himma emphasizes that the most essential point of the debate is whether the fetus is a moral person [11,12]. He writes that abortion rights opponents claim that abortion is murder and should be prohibited because the fetus is a moral person at the moment of conception and that the abortion rights proponents deny the crucial assumption that the fetus is a person. K.E. Himma argues that under dualist assumptions about the nature of the mind, the fetus is not a person until brain activity has begun. He postulates that it is a necessary condition for an object to be a moral person that it has a self and he maintains that to have a self it is necessary to have an active brain, which manifests itself by its electrical activity. 
This argument was carefully analyzed by F.J. Beckwith [13]. He remarks that dualism can be seen from the other perspective, suggested already by Thomas Aquinas. The proponents of this concept assume that the human being is composed of the body and an immaterial substance animating all parts of the body, which is, however, not identical to the sum of the parts of the physical body. The immaterial substance is also called here the soul; however, it is not located in the brain only. This way of the understanding dualism, called "the substance view" focuses on the continuation of the existence of the human being since its beginning. Beckwith discusses the cases of anencephalic children and argues that the essence of a person is not necessarily bound with the brain [13].

The paradox should be noted that the dualism of the kind «substance view» is derived from the opinions of the famous theologian Thomas Aquinas, who despite it acknowledged the concept of rather late ensoulment [13]. Nathan Nobis comprehensively and rigorously discusses Beckwith's arguments [14]. He emphasizes that the Substance View claim that fetuses and adults are the same "type" of being, the same "substance" and so "fetuses and adults are numerically identical". As is known, the Substance View tries to dilute the "Mentalistic, Consciousness Point of View". Nobis quotes Beckwith's arguments, who wrote that: "Mentalism justifies inequality, that is, the exploitation of beings with simpler mental lives by those with more complex mental lives. The idea is that if what might be called "moral status" is determined by properties that come in degrees or levels, then individuals who have them to a greater degree or level is entitled to exploit those who have them to a lesser degree or level.» Nobis undermines Beckwith's arguments. He concludes: "If killing mindless, often microscopic, fetuses is morally comparable to the Middle Passage, slavery, lynchings, burnings at the stake, segregation and the like, stronger arguments are needed to show this, since Beckwith's do not» [14].

It is yet worth noting numerous articles by F. Kissling, who sees himself as an activist of the movement "Catholics for a Free Choice (CFFC)" [15-19]. He wrote in one of his numerous articles: «Religious observers wonder why the church is so adamantly against abortion in every circumstance, despite the beliefs of its members" [16]. According to him, "in a Catholic theological context and actual state of morality, respect for women's right to abortion should be based on the following facts:

a. There is no decisive position within the Catholic Church on when the fetus becomes a person;

b. The principle of probabilism in Catholicism holds that when the Church cannot definitively answer a question, the consciences of individual Catholics must be primary and respected;

c. The absolute prohibition on abortion by the Church is not infallible" [19].

\section{Conclusion}

The people involved in the dispute do not generally know that in the essential records of religious dogma there is no data about the moral problem of abortion. The opinions of Christian clergy are based mainly on one of two possible ways of understanding the concept of the soul (personhood), taken from the statements of Thomas Aquinas, derived from the ideas of Aristotle. This is the so-called "Substance View", which does not link human personhood with the psyche, consciousness, but bases it on the theory of the presupposed existence of an immaterial soul associated with the material body right from the moment of conception [20]. This belief is not derived from religious dogma but is inferred from philosophical concepts, formed in the late middle Ages. The dispute is exacerbated by the fundamentalists who manipulate the common opinions using language distortions (e.g. calling an embryo as child or a person) and using graphic images of an abortion in late pregnancy.

The mass street protests of Polish women in 2016 arose as a result of the confrontation of these speculative arguments with conscious dignity and the rights of adult women, their concern for their own safety and the realities of the relationships with their partners. These experiences could be useful in the case of the emergence of a similar confrontation in other countries of the world.

\section{References}

1. Boyle EH, Kim M, Longhofer W (2015) Abortion liberalization in world society, 1960-2009. Am J Sociol 121(3): 882-913.

2. Cates W (2012) Abortion policy and science: can controversy and evidence co-exist? J Public Health Policy 33(3): 363-367.

3. Joffe C (2009) Abortion and medicine: A sociopolitical history". In M. Paul: Management of unintended and abnormal pregnancy. Oxford, John Wiley \& Sons Ltd, New Jersey, USA.

4. World Abortion Policies (2011) United Nations, Department of Economic and Social Affairs New York, Population Division, NY 10017, New York, USA.

5. Finer L, Fine JB (2013) Abortion law around the world: progress and pushback. Am J Public Health. 103(4): 585-589.

6. Fournet P (2016) Abortion law in France. J Gynecol Obstet Biol Reprod (Paris). 45(10): 1577-1595.

7. Taylor M (2015) Women's right to health and Ireland's abortion laws. Int J Gynaecol Obstet 130(1): 93-97.

8. Bergallo P, Ramón Michel A (2016) Constitutional developments in Latin American abortion law. Int J Gynaecol Obstet. 135(2): 228-231.

9. Keogh LA, Newton D, Bayly C, McNamee K, Hardiman A, et al. (2016) Intended and unintended consequences of abortion law reform: perspectives of abortion experts in Victoria, Australia. J Fam Plann Reprod Health Care pii: jfprhc-2016-101541.

10. Robinson BA (2013) Roman Catholicism and abortion access. Pagan \& Christian beliefs 400 BCE -1983 CE. Ontario Consultants on Religious Tolerance, Ontario, USA.

11. Himma KE (2003) What philosophy of mind can tell us about the morality of abortion: personhood, materialism, and the existence of self. Int J Appl Philos 17(1): 89-109. 
12. Himma KE (2005) A dualist analysis of abortion: personhood and the concept of self qua experiential subject. J Med Ethics 31(1): 48-55.

13. Beckwith FJ (2005) Of souls, selves, and cerebrums: a reply to Himma J Med Ethics 31(1): 56-60.

14. Nobis N (2011) Abortion, metaphysics and morality: a review of Francis Beckwith's defending life: a moral and legal case against abortion choice. J Med Philos 36: 261-273.

15. Kissling F (1990) New developments in abortion politics. Conscience 11(3): 2, 24.

16. Kissling F (1993) Religion and abortion: Roman Catholicism lost in the pelvic zone. Womens Health Issues 3: 132-137.
17. Kissling F (1993) Opposition to legal abortion: challenges and questions. Plan Parent Chall 1: 3-5.

18. Kissling F (1995) Responding to religious conservatism. Plenary speech to the Nongovernmental Forum, Fourth World Conference on Women, Beijing, 1995. Conscience16(4): 7-10.

19. Kissling F (2000) Abortion: articulating a moral view. Conscience. 21(2): 21-2, 27.

20. Roth A. 'Her story is my story': How a harsh abortion ban has reignited feminism in Poland. The, 17 October 2016 Washington Post, USA.

\section{Your next submission with Juniper Publishers will reach you the below assets}

- Quality Editorial service

- Swift Peer Review

- Reprints availability

- E-prints Service

- Manuscript Podcast for convenient understanding

- Global attainment for your research

- Manuscript accessibility in different formats

( Pdf, E-pub, Full Text, Audio)

- Unceasing customer service

Track the below URL for one-step submission https://juniperpublishers.com/online-submission.php 